\title{
Physiological, biochemical, and ultrastructural characterization of selenium toxicity in cowpea plants
}

\author{
Vinícius Martins Silva ${ }^{\mathrm{a}}$, Eduardo Henrique Marcandalli Boleta ${ }^{\mathrm{a}}$, \\ Maria Gabriela Dantas Bereta Lanza ${ }^{\mathrm{b}}$, Jose Lavres ${ }^{\mathrm{c}}$, Juliana Trindade Martins ${ }^{\mathrm{a}}$, \\ Elcio Ferreira Santos ${ }^{c}$, Flávia Lourenço Mendes dos Santos ${ }^{\mathrm{a}}$, Fernando Ferrari Putti ${ }^{\mathrm{b}}$, \\ Enes Furlani Junior ${ }^{\mathrm{a}}$, Philip J. White ${ }^{\mathrm{d}}$, Martin R. Broadley ${ }^{\mathrm{e}}$, Hudson Wallace Pereira de Carvalho ${ }^{\mathrm{c}}$, \\ André Rodrigues dos Reis ${ }^{\mathrm{a}, \mathrm{b},}$
}

\footnotetext{
a São Paulo State University - UNESP, Ilha Solteira, Postal Code 15.385-000, SP, Brazil

' São Paulo State University - UNESP, Tupã, Postal Code 17602-496, SP, Brazil

${ }^{\mathrm{c}}$ University of São Paulo - USP, Postal Code 13416-000, Piracicaba, SP, Brazil

${ }^{\mathrm{d}}$ The James Hutton Institute, Invergowrie, Dundee, DD2 5DA, UK

e School of Biosciences, The University of Nottingham, Sutton Bonington, Leicestershire, LE12 5RD, UK
}

\section{A R T I C L E I N F O}

\section{Keywords:}

Vigna unguiculata

Antioxidant metabolism

Photosynthetic pigments

Toxicity

Scanning electron microscopy

\begin{abstract}
A B S T R A C T
Selenium (Se) is considered a beneficial element for plants; however, in high concentrations, it causes negative effects on plant physiology and development. This study reports the first physiological, nutritional, and ultrastructural description of Se toxicity in cowpea growing under field conditions. Selenium was supplied as a foliar application of sodium selenite at varying concentrations $\left(0,50,100,200,400,800,1200\right.$, and $\left.1600 \mathrm{~g} \mathrm{ha}^{-1}\right)$. An increased yield was observed with the application of $50 \mathrm{~g} \mathrm{ha}^{-1}$ Se. Application of concentrations higher than $50 \mathrm{~g} \mathrm{ha}^{-1}$ caused leaf toxicity. Increased lipid peroxidation and hydrogen peroxide concentration and reduced total sugars, sucrose, and carotenoid concentration were observed at highest doses tested (1200 and $1600 \mathrm{~g} \mathrm{ha}^{-1}$ ). Applications of more than $50 \mathrm{~g} \mathrm{ha}^{-1}$ Se reduced the phloem diameter, caused chlorosis of the leaf blade with a coalescence of lesions, and caused pink salt deposits to appear. Lesions were observed mainly near the trichomes on the adaxial surface of the leaf blade. An analysis of the element distribution with microprobe Xray fluorescence spectrometry $(\mu-\mathrm{XRF})$ revealed accumulation of Se, calcium (Ca), potassium (K), copper (Cu), and manganese (Mn) near the primary vein and in the necrotic brown areas of the leaf lesions. In contrast, $\mathrm{Na}$ was homogeneously distributed in the leaf tissue.
\end{abstract}

\section{Introduction}

Selenium (Se) is a micronutrient essential to metabolism in humans and animals. It is involved in thyroid function and the immune system and is also an antioxidant (Fairweather-Tait et al., 2011). In plants, Se is considered a beneficial trace element that can promote growth and help resist oxidative, biotic, and abiotic stress (White, 2016; Reis et al., 2017a, 2017b).

The concentrations of Se in agricultural food products depend on the availability of this element in the soil (Joy et al., 2015). Se concentrations tend to be very low (below $1 \mathrm{mg} \mathrm{kg}^{-1}$ ) in plants growing in acidic and weathered conditions such as tropical soils (Pilon-Smits et al., 2009) and the Se deficiency is estimated to be a problem for more than 1 billion people (Combs, 2001; Schiavon and Pilon-Smits, 2017).
Therefore, Se supplementation to plants might be an important strategy for increasing the daily intake of this element by humans and animals (White and Broadley, 2009; Chilimba et al., 2012; White, 2016; Reis et al., 2017a, 2017b).

Cowpea (Vigna unguiculata (L.) Walp.) is an important legume due to its high nutritional value, adaptability, and versatility to different production conditions (Ehlers and Hall, 1997). Due to its resistance to water loss, it is suitable to hot arid regions (Hall, 2012). Cowpea also has a role as a dietary protein and mineral source, complementing cereals, tuberous vegetables, and root vegetables in diets in various developing countries in Africa, Latin America, and Asia (Phillips et al., 2003; Manzeke et al., 2017).

In spite of its nutritional importance, the range between deficient and toxic levels of Se is narrow (Schiavon and Pilon-Smits, 2017). Large

\footnotetext{
* Corresponding author at: São Paulo State University - UNESP, Tupã, Postal Code 17.602-496, SP, Brazil.

E-mail address: andrereis@tupa.unesp.br (A.R.d. Reis).
} 
Se concentrations may affect the development of plants, such as cowpea. The tolerated Se concentrations, as well as toxicity mechanisms, vary depending on the plant species (White et al., 2004).

The stress caused by high doses of Se in plants may change the concentrations of reactive species of oxygen (ROS) such as $\mathrm{H}_{2} \mathrm{O}_{2}$ and induce high lipid peroxidation rates in cell membranes (Mostofa et al., 2017). ROS are an indicative of stress in plants, indicating the damage to the plant cell but also act as signaling molecules in response to stressful compounds in the plant tissues (Wrzaczek et al., 2013; Shi et al., 2016; Luo et al., 2016). The abiotic stress in plants is evaluated also by the increase of antioxidative enzymes such as peroxidase (POD), superoxide dismutase (SOD), and catalase (CAT) in response to high levels of heavy metal exposure (Reis et al., 2017a, 2017b; Santos et al., 2017).

The most effective option for Se fertilization in crops is through foliar application, with the absorption and distribution being twice as efficient compared to soil application or seed treatment (Broadley et al., 2006; White and Broadley, 2009; Broadley et al., 2010; Chilimba et al., 2012; Ros et al., 2016). Foliar application places the solution directly in contact with the stomata and very close to the mesophyll. Thus, at high doses, a high risk exists of rapidly damaging the production of photoassimilates; high doses may also cause the accumulation of ROS, slow development, and decreased concentration of photosynthetic pigments (Molnárová and Fargašová, 2009).

Effects of large plant Se concentrations include a reduced number of chloroplasts in the mesophyll cells and the degradation of the cytoplasm, nucleus, and organelles in root meristems (Fatalieva, 1987; Ślusarczyk et al., 2015). However, information on the toxic effects of Se on plant ultrastructure, especially following foliar application, is still scarce.

No detailed information is available in the literature on the physiology and ultrastructure of plants grown under field conditions in response to the foliar application of sodium selenite. The present study presents a characterization of toxicity in cowpea based on the results obtained from antioxidant metabolism; from the analysis of histological, ultrastructural, and nutritional changes, and from the location of Se in different parts of the plant tissue analyzed through microprobe Xray fluorescence spectrometry $(\mu-\mathrm{XRF})$.

\section{Materials and methods}

\subsection{Experimental area}

The experiments were conducted at the Teaching, Research and Extension Farm of São Paulo State University (UNESP) in the municipality of Selviria, Mato Grosso do Sul State, Brazil (20 $20^{\prime} 43^{\prime \prime}$; $51^{\circ} 24^{\prime \prime} 7^{\prime \prime} \mathrm{W}, 355 \mathrm{~m}$ ). The soil type is Distroferric Red Latosol with clayey texture (Demattê, 1980; EMBRAPA, 2013), with the following chemical characteristics: $\mathrm{pH}\left(\mathrm{CaCl}_{2} 0.01 \mathrm{M}\right) 5.2$; phosphorus (resin) $34 \mathrm{mg} \mathrm{dm}^{-3}$; sulfur (calcium phosphate) $8 \mathrm{mg} \mathrm{dm}^{-3}$; potassium (resin) $2.7 \mathrm{mmol}_{\mathrm{c}} \mathrm{dm}^{-3}$; calcium (resin) $14 \mathrm{mmol}_{\mathrm{c}} \mathrm{dm}^{-3}$; magnesium (resin) $14 \mathrm{mmol}_{\mathrm{c}} \mathrm{dm}^{-3} ; \mathrm{H}+\mathrm{Al}$ (SMP buffer) $26 \mathrm{mmol}_{\mathrm{c}} \mathrm{dm}^{-3}$; cation exchange capacity $56.7 \mathrm{mmol}_{\mathrm{c}} \mathrm{dm}^{-3}$; base saturation $54 \%$; boron (hot water) $0.19 \mathrm{mg} \mathrm{dm}^{-3}$; copper (DTPA) $2.7 \mathrm{mg} \mathrm{dm}^{-3}$; iron (DTPA) $19 \mathrm{mg} \mathrm{dm}^{-3}$; manganese (DTPA) $12.4 \mathrm{mg} \mathrm{dm}^{-3}$; zinc (DTPA) $6.1 \mathrm{mg} \mathrm{dm}^{-3}$; total Se $62 \mathrm{\mu g} \mathrm{kg}^{-1}$, and organic matter $18 \mathrm{~g} \mathrm{dm}^{-3}$. These chemical characteristics were determined as described by Raij et al. (1997) after the collection of composite soil samples from 0 to $20 \mathrm{~cm}$ depth on September 10, 2016.

The experiment used a randomized complete block design, with four blocks and eight Se concentrations (0, 50, 100, 200, 400, 800, 1200, and $\left.1600 \mathrm{~g} \mathrm{ha}^{-1}\right)$, in four replicates. Sodium selenite $\left(\mathrm{Na}_{2} \mathrm{SeO}_{3}\right)$ was used as the Se source. Each experimental plot was composed of five 3$\mathrm{m}$-long rows in $0.45 \mathrm{~m}$ intervals, for a total parcel area of $6.75 \mathrm{~m}^{2}$.

\subsection{Experiment setup and procedure}

The soil was prepared with subsoiling, heavy disking, medium disking (twice), and leveling. Sowing was carried out on October 18, 2016 , with spacing of $0.45 \mathrm{~m}$ between rows and a sowing density of 11.2 seeds $\mathrm{m}^{-1}$. Fertilization of the planting furrow consisted of $20 \mathrm{~kg} \mathrm{ha}^{-1} \mathrm{~K}_{2} \mathrm{O}$ applied as $\mathrm{KCl}\left(33 \mathrm{~kg} \mathrm{ha}^{-1}\right)$ and $20 \mathrm{~kg} \mathrm{ha}^{-1} \mathrm{P}_{2} \mathrm{O}_{5}$ applied as single superphosphate $\left(110 \mathrm{~kg} \mathrm{ha}^{-1}\right)$.

Cowpea seeds (Vigna unguiculata (L.) Walp.) of the BRSTumucumaque variety were treated with pyraclostrobin $\left(25 \mathrm{gL}^{-1}\right.$ commercial product), thiophanate-methyl $\left(225 \mathrm{~g} \mathrm{~L}^{-1}\right.$ commercial product), and fipronil ( $250 \mathrm{~g} \mathrm{~L}^{-1}$ commercial product) at $2 \mathrm{~mL}$ product per $\mathrm{kg}$ of seeds. After the seeds were dried, they were inoculated with a premium peat inoculum for cowpea (strain SEMIA 6462, product registration number SP 00581-10030-1, $2.0 \times 10^{9}$ colony forming units $\mathrm{g}^{-1}$, BIOMAX, São Joaquim da Barra city, Brazil), at $8 \mathrm{~g} \mathrm{~kg}^{-1}$ of seed. The inoculum was dissolved in a sugar solution ( $1 \mathrm{~mL}$ of water per gram of inoculant, $10 \%$ sugar) and gradually added and mixed with the seeds in a concrete mixer at a constant speed of $18 \mathrm{rpm}$ for $5 \mathrm{~min}$. Emergence began on October 22, 2016, four days after sowing (4 DAS).

At 40 days after emergence (DAE), the Se treatments were applied at $0,50,100,200,400,800,1200$, and $1600 \mathrm{~g} \mathrm{ha}^{-1}$ as sodium selenite diluted in water at $200 \mathrm{~L} \mathrm{ha}^{-1}$, by foliar application from a backpack sprayer calibrated for $28 \mathrm{~mL}$ of solution per row of cowpea. Additional treatments were carried out at $15 \mathrm{DAE}$ (abamectin, $0.50 \mathrm{~L} \mathrm{ha}^{-1}$ commercial product for mite control), $23 \mathrm{DAE}$ (bentazone, $0.8 \mathrm{~L} \mathrm{ha}^{-1}$ for weed control; abamectin, $0.5 \mathrm{~L} \mathrm{ha}^{-1}$ and imidacloprid, $0.4 \mathrm{~L} \mathrm{ha}^{-1}$ for whitefly control), and at $33 \mathrm{DAE}$ (haloxyfop-p-methyl, $0.3 \mathrm{~L} \mathrm{ha}^{-1}$ for weed control).

\subsection{Determination of antioxidant metabolism}

Trifoliate leaves of the upper third of 10 plants were collected from each plot $48 \mathrm{~h}$ after Se application and stored in liquid nitrogen $(\mathrm{N})$. Leaf material was macerated in liquid $\mathrm{N}$ and stored in a freezer at $-80^{\circ} \mathrm{C}$ until it was processed for analyses of hydrogen peroxide concentration, lipid peroxidation, superoxide dismutase (SOD) activity, catalase (CAT) activity, ascorbate peroxidase (APX) activity, and glutathione reductase (GR) activity.

Lipid peroxidation was estimated based on the concentration of malondialdehyde (MDA) according to Heath and Packer (1968). Determination of the hydrogen peroxide concentration $\left(\mathrm{H}_{2} \mathrm{O}_{2}\right)$ was carried out as described by Alexieva et al. (2001). For the determination of protein and the activity of superoxide dismutase (SOD, EC:1.15.1.1), catalase (CAT, EC:1.11.1.6), ascorbate peroxidase (APX, EC:1.11.1.11), and glutathione reductase (GR, EC:1.6.4.2), the material was weighed and prepared according to the methodology described by Gomes-Junior et al. (2007). The concentration of the total soluble protein was determined according to Bradford (1976). The SOD activity was quantified as described by Giannopolitis and Ries (1977). The CAT activity was determined by monitoring $\mathrm{H}_{2} \mathrm{O}_{2}$ degradation as described by Azevedo et al. (1998). The APX activity was measured as described by Moldes et al. (2008). The GR was quantified as described by GomesJunior et al. (2006).

\subsection{Determination of total sugar concentration and sucrose}

The sugar concentration was determined from leaf samples extracted in $10 \mathrm{~mL}$ of MCW solution (60\% methanol, $25 \%$ chloroform, and $15 \%$ water) and prepared for analyses as described by Bieleski and Turner (1966). Total sugar was quantified according to the protocols in Dubois et al. (1956), and sucrose was quantified according to Van Handel (1968). 


\subsection{Determination of the concentrations of photosynthetic pigments}

Photosynthetic pigments (chlorophylls and carotenoids) were extracted and analyzed according to the method described by Lichtenthaler (1987) from plant tissue extracted in $80 \%$ acetone solution.

\subsection{Nutrient analysis}

Leaf samples were collected for nutrient analysis 16 days after the application of Se. The third trifoliate leaf (counting from the apex) was removed, dried in an oven at $40{ }^{\circ} \mathrm{C}$ to a constant mass, and ground in a Wiley mill. The determinations of phosphorus (P), potassium (K), calcium (Ca), magnesium (Mg), sulfur (S), boron (B), copper (Cu), iron $(\mathrm{Fe})$, manganese $(\mathrm{Mn})$, zinc ( $\mathrm{Zn})$, nickel $(\mathrm{Ni})$, and selenium (Se) concentrations were conducted by inductively coupled plasma-mass spectrometry (ICP-MS) according to Thomas et al. (2016).

\subsection{Stereomicroscopy, histological analysis, scanning electron microcopy, and $\mu$-XRF}

Morphometric measurements and photomicrographs of plant tissue were obtained with a computerized LAZ V4 (Leica Application Suite) image analysis system adapted to an APO S8-Leica stereomicroscope.

Leaf tissue destined for histological and ultrastructural analysis by scanning electron microscopy was fixed in FAA 70 (37\% formaldehyde, acetic acid, and $70 \%$ ethanol at 1:1:18-v:v:v ratio) as described by Lavres Junior et al. (2010). Histological analyses followed the methods described by Santos et al. (2017).

The location of Se and other elements in plant tissue was determined on excised trifoliate leaves using $\mu$-XRF with an EDAX ORBIS PC analyzer. The distribution of elements in both healthy areas and tissue injured by the application of sodium selenite were characterized.

\subsection{Yield components}

The following parameters were analyzed to evaluate the effect of sodium selenite on yield components 37 days after application: plant height (PH), number of pods per plant (NPP), number of seeds per pod (NSP), pod length (PL), 100-seeds mass, and yield. The PH was estimated as the average height of four randomly selected plants in each plot. The NPP was calculated as the average of the total number of pods in four randomly selected plants per plot; ten pods from each of these four plants were selected to estimate PL and NSP. Harvesting was conducted by the selection of two homogeneous rows from each plot, from which all pods were manually harvested. The seeds were then weighed to obtain an estimate of yield, and 100 seeds were counted and weighed to determine the 100-seed mass. Yield and 100-seed mass were determined from seeds kept at $13 \%$ humidity.

\subsection{Statistical analysis}

The results were first submitted to Anderson-Darling normality tests; homogeneity was evaluated with Leven's test and, finally, with a variance analysis (F test). Differences between treatments were compared using a Tukey test at $5 \%$ probability or a polynomial regression, depending on the data set. Analyses were conducted using Minitab software, and graphs were prepared using SigmaPlot 12.5.

\section{Results}

\subsection{Antioxidant metabolism response}

The application of the sodium selenite had a significant effect on lipid peroxidation (MDA) (Fig. 1a) and on hydrogen peroxide concentration (Fig. 1b). Foliar application of Se up to $800 \mathrm{~g} \mathrm{ha}^{-1}$ was associated with a reduction in lipid peroxidation relative to the control. A Se application of $1200 \mathrm{~g} \mathrm{ha}^{-1}$ led to a $46 \%$ increase in the lipid peroxidation rates relative to the control. The highest rates of lipid peroxidation were recorded in leaves of plants that received $1600 \mathrm{~g} \mathrm{ha}^{-1} \mathrm{Se}$, which had a rate of lipid peroxidation 3.5 times greater than the control.

An increase in hydrogen peroxide concentration was observed with the application of Se at $50-800 \mathrm{~g} \mathrm{ha}^{-1}$; however, these values were less than the $\mathrm{H}_{2} \mathrm{O}_{2}$ concentration recorded for the control treatment (Fig. 1b). On the other hand, the application of $1600 \mathrm{~g} \mathrm{ha}^{-1}$ increased the hydrogen peroxide concentration by $35 \%$ compared to the control treatment.

The application of Se affected the specific activity of SOD, CAT, APX, and GR in cowpea leaf tissue (Fig. 2). The highest SOD activity (Fig. 2a) was observed in plants that received $1200 \mathrm{~g} \mathrm{ha}^{-1}$ Se. However, increased activity of this enzyme was also observed in the plants that received 100 and $800 \mathrm{~g} \mathrm{ha}^{-1}$. The SOD activity in the other treatments did not differ significantly from the control.

The CAT activity (Fig. 2b) in leaves increased with increasing Se applications up to $100 \mathrm{~g} \mathrm{ha}^{-1}$. Selenium applications greater than $100 \mathrm{~g} \mathrm{ha}^{-1}$ induced a marked decrease in CAT activity. No significant changes were observed in the APX activity in leaves (Fig. 2c) with Se applications up to $800 \mathrm{~g} \mathrm{ha}^{-1}$; however, the application of $1200 \mathrm{~g} \mathrm{ha}^{-1}$ Se led to an APX activity 3.6 times greater than the control.

The GR activity (Fig. 2d) increased with increasing Se applications up to 100 and $200 \mathrm{~g} \mathrm{ha}^{-1}$. The greater GR activity was recorded in the plants that received $1200 \mathrm{~g} \mathrm{ha}^{-1}$, which had a GR activity 2.3 times greater than the control.

\subsection{Photoassimilates and photosynthetic pigments}

The application of sodium selenite affected the concentrations of sucrose, total sugars, total chlorophylls, and carotenoid concentration in cowpea leaves (Fig. 3). Sucrose concentration in leaves (Fig. 3a) increased with increasing Se application to a maximum in plants that received $400 \mathrm{~g} \mathrm{ha}^{-1}$, then decreased as Se applications were increased further. A similar result was obtained for total sugars (Fig. 3b), which increased with increasing Se applications up to $400 \mathrm{~g} \mathrm{ha}^{-1}$.

Total chlorophyll concentration of leaves (Fig. 3c) decreased with increasing Se applications up to $200 \mathrm{~g} \mathrm{ha}^{-1}$. However, the chlorophyll concentration increased in leaves of plants that received 400 and $800 \mathrm{~g} \mathrm{ha}^{-1}$ and decreased again as more Se was applied. The highest concentrations of photosynthetic pigments were observed in the control. The concentration of carotenoids (Fig. 3d) increased in leaves of plants that received $100 \mathrm{~g} \mathrm{ha}^{-1} \mathrm{Se}$. The smallest concentrations of carotenoids were recorded in plants that received 400 and $1600 \mathrm{~g} \mathrm{ha}^{-1}$ Se.

\subsection{Yield components and nutritional analysis}

Selenium application affected the 100-seed mass and overall yield of cowpea plants (Supplementary material 1). No significant response to Se application was observed for PH, NPP, PL, or NSP (Supplementary material 1a-d). The control plot showed the highest 100-seeds mass (Supplementary material 1e), with this value decreasing with increasing Se application. The largest overall yield (Supplementary material $1 \mathrm{~b}$ ) was obtained with plants that received $50 \mathrm{~g} \mathrm{ha}^{-1} \mathrm{Se}$, which yielded 1.6 times that of plants receiving no Se. For other treatments, the yield did not differ significantly from the control.

The concentrations of Se (Fig. 4a, b) and Na (Fig. 4c, d) in leaves and seeds were affected by the application of sodium selenite. The concentration of Se increased with increasing Se applications, whereas $\mathrm{Na}$ concentrations fitted a polynomial second-order regression model. The application of sodium selenite also affected leaf concentrations of $\mathrm{P}, \mathrm{Mg}, \mathrm{K}$, and $\mathrm{S}$, and the Ca concentration in the seeds (Supplementary material 2). Plants that received $100 \mathrm{gha}^{-1}$ Se showed a $9.5 \%$ 
(a)

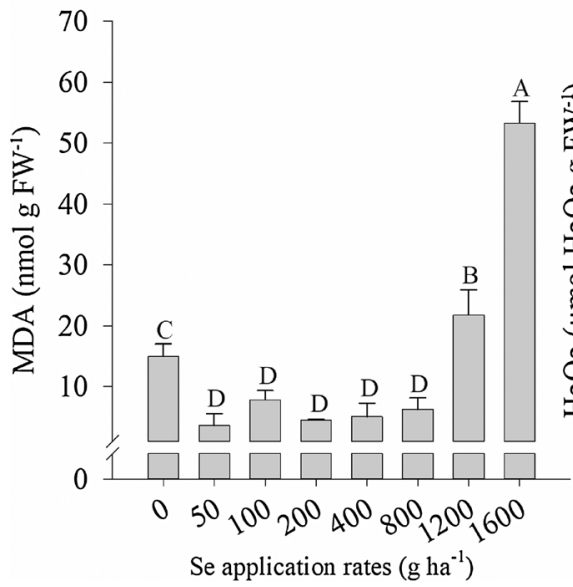

(a)

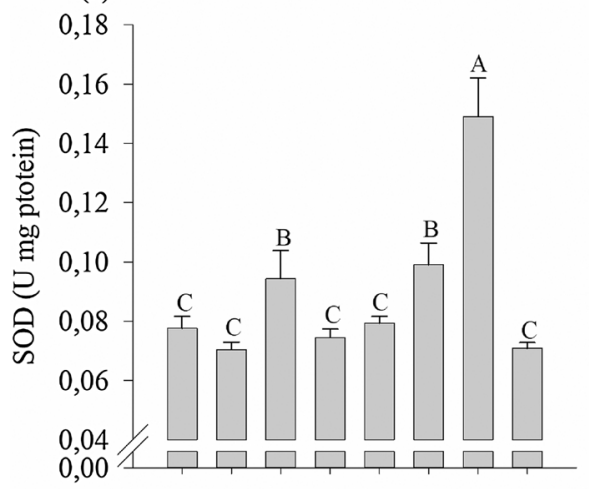

(c)

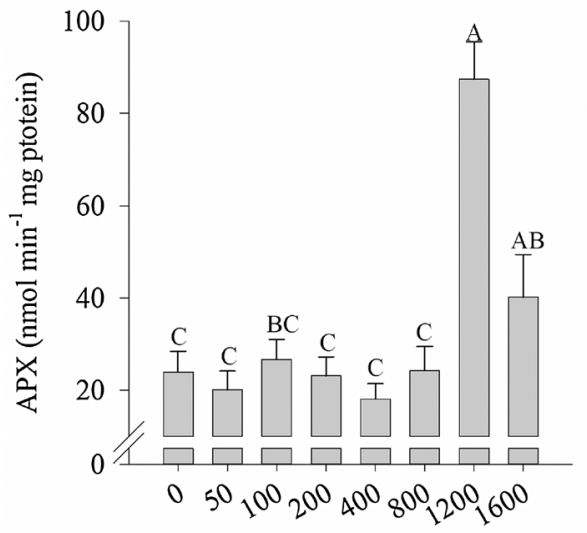

Se application rates $\left(\mathrm{g} \mathrm{ha}^{-1}\right)$

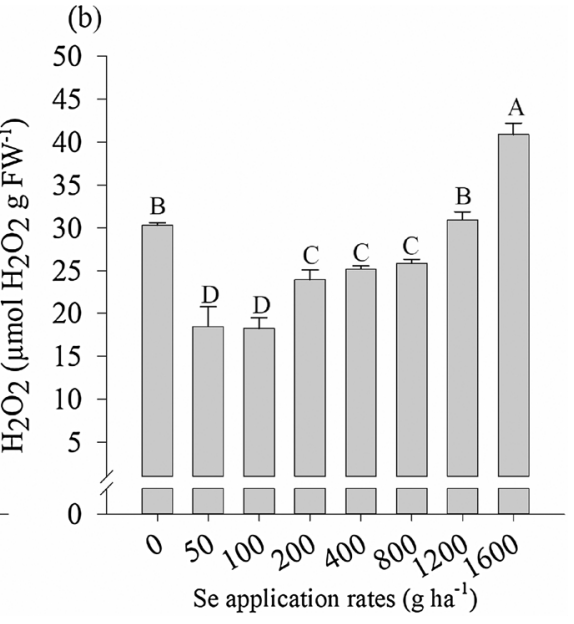

Fig. 1. Estimates of lipid peroxidation assayed (a) by MDA concentration and (b) hydrogen peroxide concentration in the third trifoliate leaves of cowpea plants sprayed with sodium selenite at various application rates. Error bars indicate the standard error of the mean ( $n=4$ replicates); identical letters indicate that no significant difference exists between the means according to the Tukey test ( $\mathrm{p} \leq 0.05)$. CV(\%) $=16.60$ (a) and 3.06 (b).

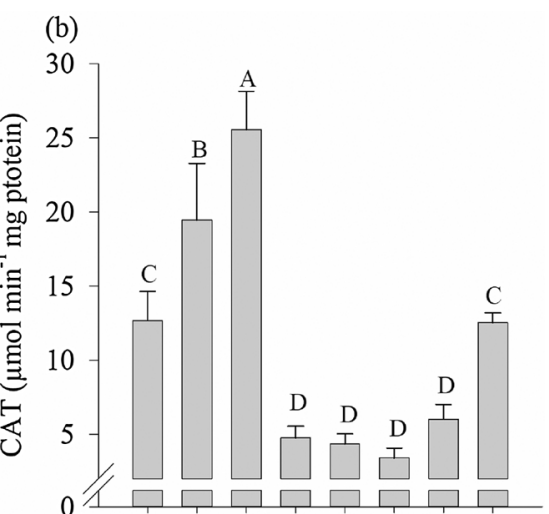

(d)

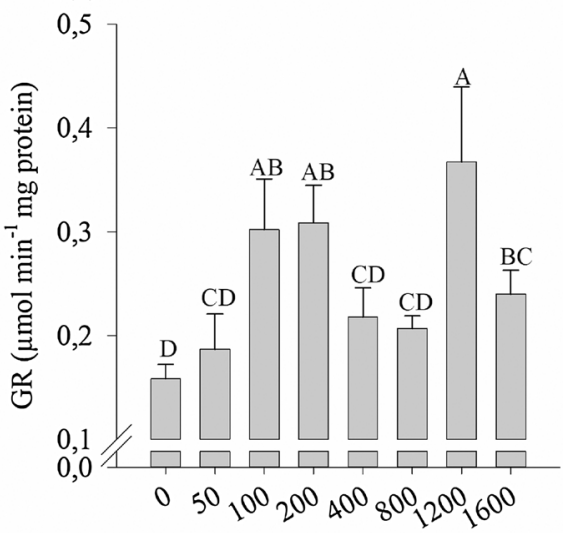

Se application rates $\left(\mathrm{g} \mathrm{ha}^{-1}\right)$
Fig. 2. Specific activity of (a) superoxide dismutase, (b) catalase, (c) ascorbate peroxidase, and (d) glutathione reductase in the third trifoliate leaves of cowpea plants sprayed with sodium selenite at various application rates. Error bars indicate the standard error of the mean ( $n=4$ replicates); identical letters indicate that no significant difference exists between the means according to the Tukey test ( $\mathrm{p} \leq 0.05$ ). CV $(\%)=6.22$ (a), 17.39 (b), 17.76 (c), and 13.65 (d). decreased in $\mathrm{P}$ concentration relative to the control (Supplementary material 2a) and a $12 \%$ increase in $\mathrm{Mg}$ concentration in the leaves (Supplementary material $2 \mathrm{~b}$ ). Plants that received $1200 \mathrm{~g} \mathrm{ha}^{-1}$ showed similar K concentrations to the control; other concentrations led to a reduction of at least $24 \%$ in the $\mathrm{K}$ concentration (Supplementary material 2c). A decrease was also observed in the $S$ concentration in plants that received 50 and $200 \mathrm{~g} \mathrm{ha}^{-1}$ (Supplementary material 2d). An increased concentration of $\mathrm{Ca}$ was observed in seeds that received $800 \mathrm{~g} \mathrm{ha}^{-1}$ applications (Supplementary material 2e), corresponding to an increase of $38 \%$ relative to the control.

The application of sodium selenite also affected the concentrations of $\mathrm{B}, \mathrm{Cu}, \mathrm{Fe}, \mathrm{Mn}$, and $\mathrm{Zn}$ in the leaves and the $\mathrm{Cu}, \mathrm{Mn}$, and $\mathrm{Ni}$ in the seed (Supplementary material 3). Plants that received $1200 \mathrm{~g} \mathrm{ha}^{-1}$ Se had the largest concentrations of B (Supplementary material 3a). The amounts for $\mathrm{Cu}$ recorded for the plants that received 50 and $100 \mathrm{~g} \mathrm{ha}^{-1}$ were close to the control, whereas in other treatments, a decrease was observed in the $\mathrm{Cu}$ concentration (Supplementary material $3 \mathrm{~b}$ ), with the largest concentration being observed in plants that received $200 \mathrm{~g} \mathrm{ha}^{-1}$ Se. For Fe (Supplementary material 3c), the largest concentrations were observed in plants that received $1200 \mathrm{~g} \mathrm{ha}^{-1}, 1.45$ times that of the control. Increased concentrations of Mn were recorded in plants that received sodium selenite (Supplementary material 3d), with smaller values being observed only for the $400 \mathrm{~g} \mathrm{ha}^{-1}$ treatment, both in the leaves and seeds. Control plants showed the highest leaf concentrations for $\mathrm{Zn}$ (Supplementary material 3e), with similar results obtained in the plants that received 100,800 , and $1200 \mathrm{~g} \mathrm{ha}^{-1} \mathrm{Se}$. The 

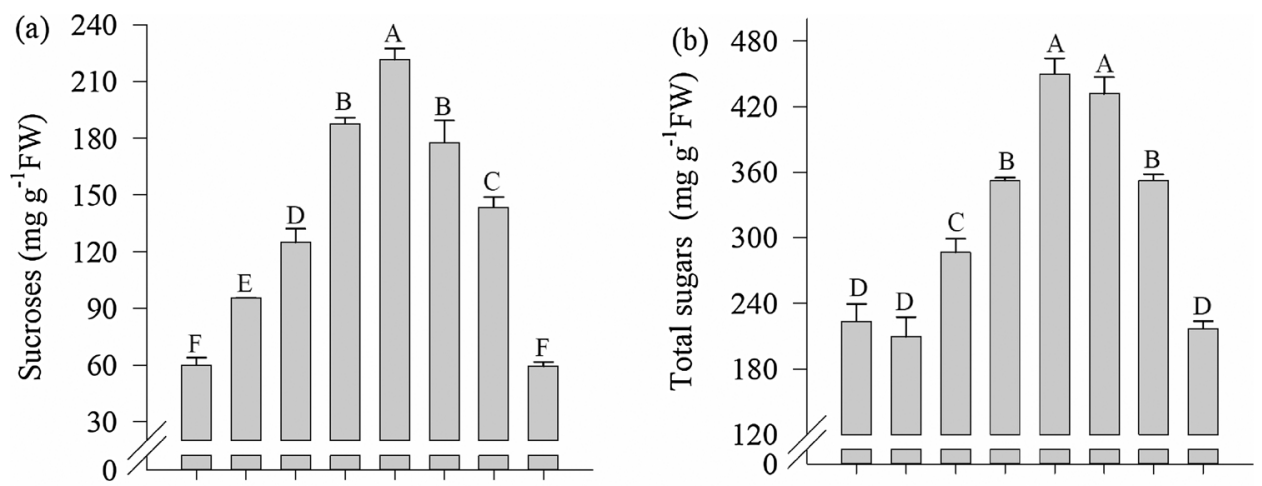

Fig. 3. Concentrations of (a) sucrose, (b) total sugar, (c) chlorophylls A + B and (d) carotenoids in the third trifoliate leaves of cowpea plants sprayed with sodium selenite at various application rates. Error bars indicate the standard error of the mean ( $\mathrm{n}=4$ replicates); identical letters indicate that no significant difference exists between the means according to the Tukey test ( $\mathrm{p} \leq 0.05)$. $\mathrm{CV}(\%)=4.68$ (a), 4.20 (b), 23.68 (c), and 36,70 (d).
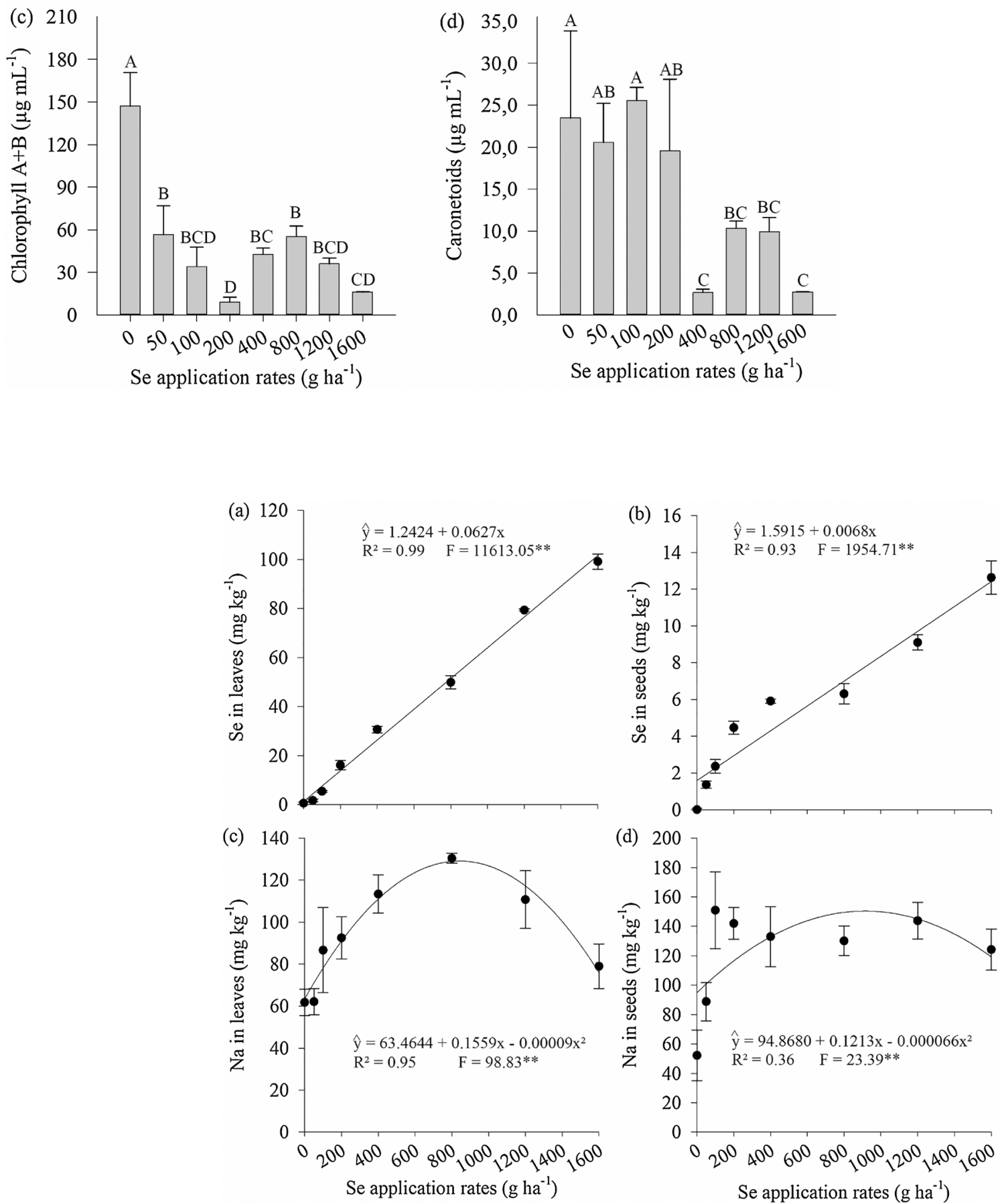

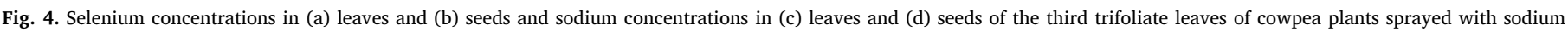
selenite at various application rates. Error bars indicate the standard error of the mean $(n=4$ replicates). 

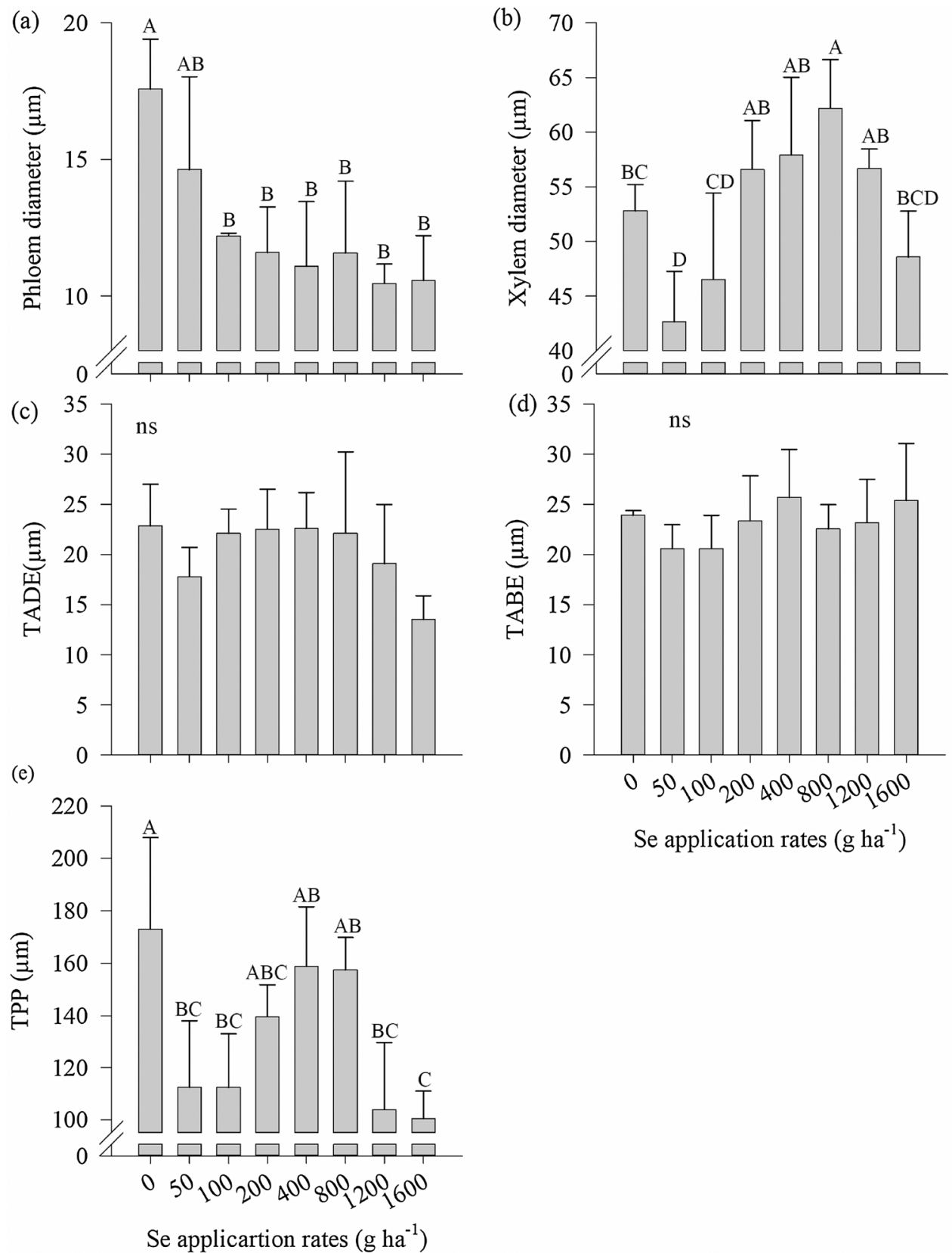

Se application rates $\left(\mathrm{g} \mathrm{ha}^{-1}\right)$

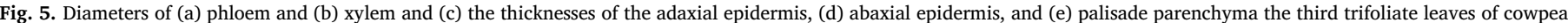

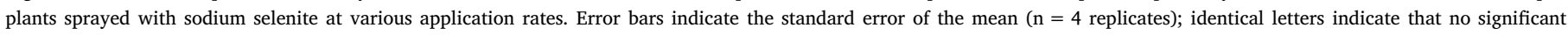
difference exists between the means according to the Tukey test. ( $\mathrm{p} \leq 0.05$ ), ns = not significant. CV(\%) = 16.41 (a), 7.43 (b), 17.57 (c), 23.24 (d) and 17.69 (e).

Zn concentrations were lower than the control in all other treatments. Selenium application led to decreased amounts of $\mathrm{Ni}$ in the seeds (Supplementary material $3 \mathrm{f}$ ), with the most marked decrease having been observed in the highest doses of Se $\left(1600 \mathrm{~g} \mathrm{ha}^{-1}\right)$.

\subsection{Ultrastructure and $\mu$-XRF nutrient distribution analysis}

The application of sodium selenite affected the diameter of the phloem and xylem and the thickness of the palisade parenchyma of cowpea leaves (Fig. 5). The application of sodium selenite reduced the diameter of the phloem (Fig. 5a). The largest phloem diameter was observed in the control treatment, with a reduction observed in plants treated with sodium selenite. Variation in the xylem diameter (Fig. 5b) was also observed, with the smallest diameter being recorded for plants that received sodium selenite. The largest values for palisade parenchyma thickness (Fig. 5e, Supplementary material 4a) were observed in the control, and a significant reduction occurred in the thickness of the tissue of plants under applications of 50, 100 1200, and $1600 \mathrm{~g} \mathrm{ha}^{-1}$ (Supplementary material 4b-h).

The symptoms of toxicity of the cowpea leaves in response to application of Se is shown in Fig. 6. Foliar applications of concentrations above $50 \mathrm{gha}^{-1}$ were sufficient to promote necrotic lesions in the adaxial surface of the leaves. Toxicity is characterized by chlorosis of the leaf blade, resulting in brown-colored borders. When concentrations were above $200 \mathrm{~g} \mathrm{ha}^{-1}$ (Fig. 6e-h), the lesions coalesced, and pink saline deposits were observed within them. At doses higher than $800 \mathrm{~g} \mathrm{ha}^{-1}$ (Fig. 6g-h), obstruction of the leaf conductive vessels was observed.

In scanning electron microscopy analyses (Fig. 7), toxicity was observed mostly as lighter shade spots (Fig. $7 \mathrm{c}-\mathrm{h}$ ), but closure of the stomata and other cells (Fig. 7e-h) also occurred.

Fig. 8 illustrates the distribution of the elements shown through $\mu$ - 

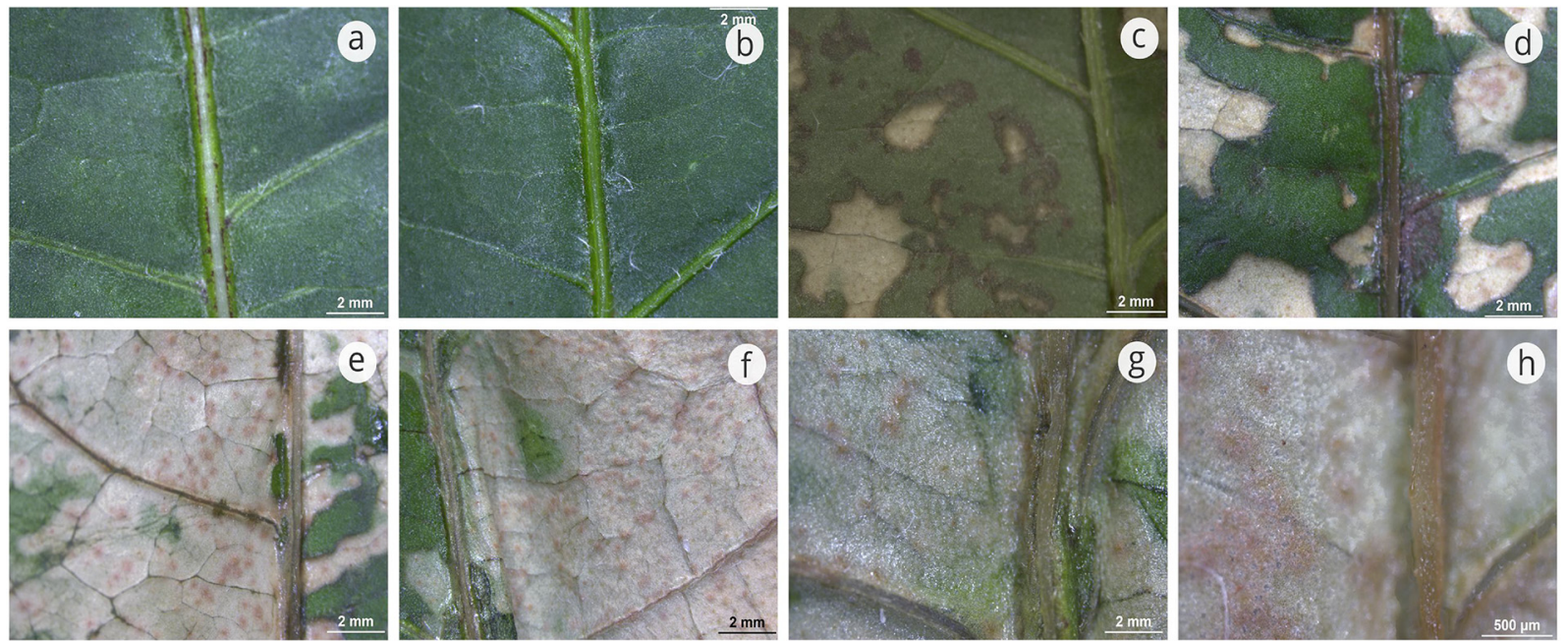

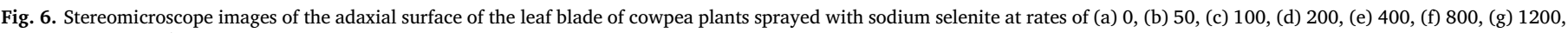
and (h) $1600 \mathrm{~g} \mathrm{ha}^{-1} \mathrm{Se}$

$\mathrm{XRF}$ in cowpea leaves in response to Se application at $1600 \mathrm{~g} \mathrm{ha}^{-1} \mathrm{Se}$. High K- $\alpha$ values for Se (Fig. 8b), S (Fig. 8c), Ca (Fig. 8d), K (Fig. 8e), Co (Fig. 8g), Cu (Fig. 8h), and Mn (Fig. 8i) were observed mainly in the leaf conductive vessels. On the other hand, Na (Fig. 8d) seemed to be homogeneously distributed, with the green areas presenting higher readings for the element. The $\mathrm{Na}$ (Fig. 8d) and Ca (Fig. 8e) concentrations were highest in the cowpea leaves.

For the characterization of the foliar lesion caused by the application of $1600 \mathrm{~g} \mathrm{ha}^{-1}$ of Se, the distribution of nutrients in the various regions of the plant tissue was analyzed using the line-scan technique (Fig. 9). The red line in Fig. 9a represents the scanned area. The highest $\mathrm{K}-\alpha$ readings for $\mathrm{Se}, \mathrm{P}, \mathrm{Ca}$, and $\mathrm{K}$ were observed in the region of the conductive vessels, followed by a higher count in the brown necrotic lesion area. The Se showed higher K- $\alpha$ readings than the $\mathrm{P}$ in the plant tissue (Fig. 9b). Regions with higher Se values had low $S$ values (Fig. 9c). Sodium was the only element that showed homogeneous distribution in the leaf and was not similar to the K- $\alpha$ distribution of Se in the leaf (Fig. 9d). Calcium, on the other hand, showed a high degree of similarity with the distribution of Se (Fig. 9e). Potassium (Fig. 9f) also showed similar distribution to Se in the conductive vessels and in the injured areas of the leaf.

\section{Discussion}

\subsection{Antioxidant metabolism response}

Although cowpea plants had a toxic reaction when exposed to more than $50 \mathrm{~g} \mathrm{ha}^{-1}$ Se (Figs. 6 and 7), lipid peroxidation and $\mathrm{H}_{2} \mathrm{O}_{2}$ concentration indicated stress in plants that received high concentrations (Fig. 1). This is likely due to the increased enzymatic activities that are stimulated by plant stress; these activities are mainly observed in the increased activity of CAT (Fig. 2b) and GR (Fig. 2d) in plants exposed to low and intermediate doses of Se.

The increase in enzyme activity may have helped to maintain the MDA and $\mathrm{H}_{2} \mathrm{O}_{2}$ concentration at levels lower than in the control because CAT converts $\mathrm{H}_{2} \mathrm{O}_{2}$ into $\mathrm{H}_{2} \mathrm{O}$ and $\mathrm{O}_{2}$ (Igamberdiev and Lea, 2002) and GR catalyzes reduction of oxidized glutathione (GSSG) into reduced glutathione (GSH), an important compound in resistance to oxidative stress (Noctor et al., 2012). The reduction in hydrogen peroxide concentration in all treatments where the applied Se concentrations were lower than $1200 \mathrm{~g} \mathrm{ha}^{-1}$ (Fig. 1b) demonstrates the action of these enzymes. The decrease in lipid peroxidation follows a pattern similar to that of the peroxide concentration, given that the release of MDA occurs due to the destructive action of the reactive oxygen species (ROS) on cell membranes.
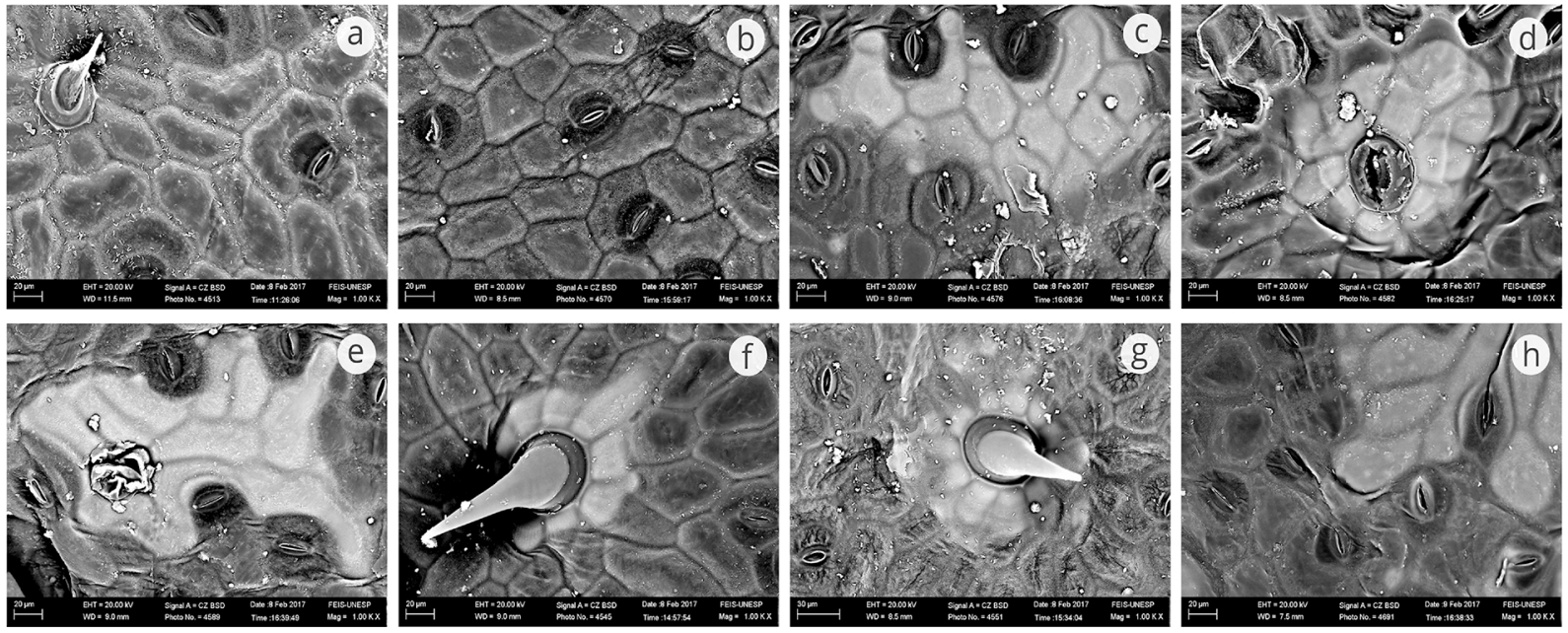

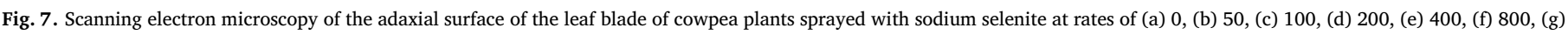
1200 , and (h) $1600 \mathrm{~g} \mathrm{ha}^{-1} \mathrm{Se}$. 

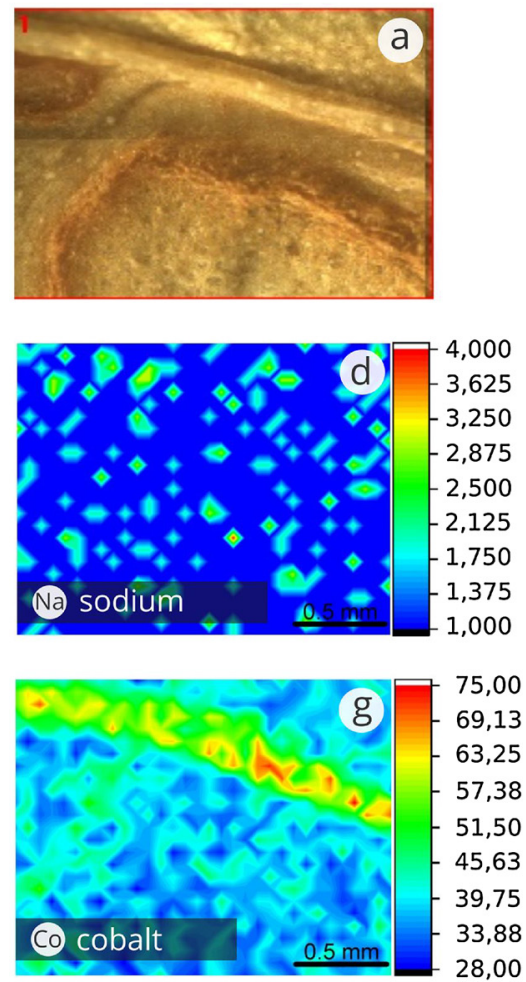
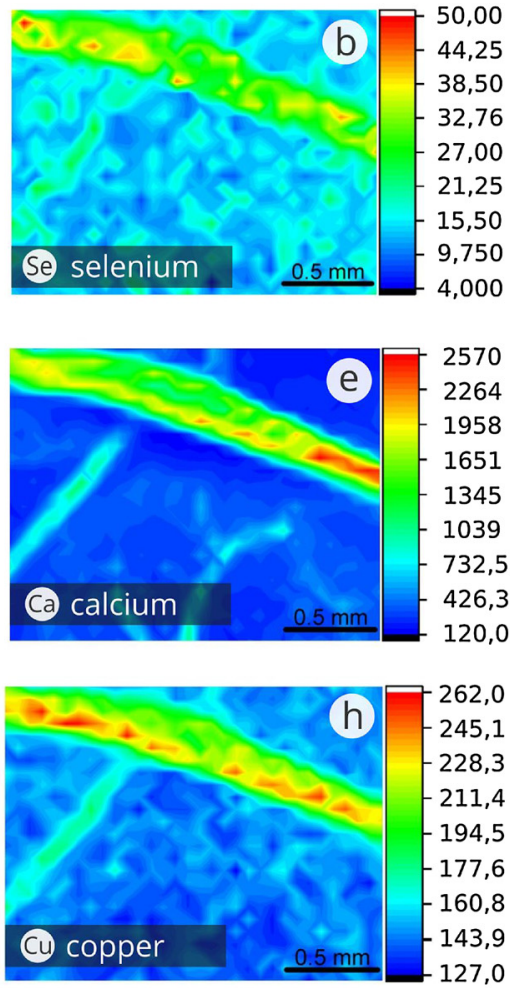
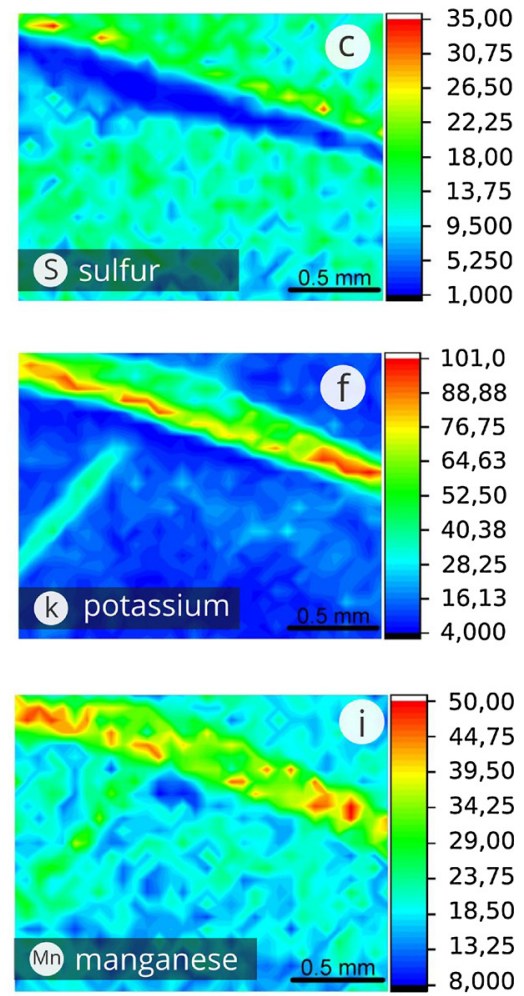

Fig. 8. Distribution maps of elements in leaves of cowpea plants sprayed with Se at $1600 \mathrm{~g} \mathrm{ha}^{-1}$ Se observed using $\mu$-XRF.

SOD showed a larger increase with very high concentrations of Se $\left(1200 \mathrm{~g} \mathrm{ha}^{-1}\right)$. This enzyme is responsible for the dismutation of $\mathrm{O}_{2^{-}}$ into $\mathrm{H}_{2} \mathrm{O}_{2}$ (Fukai and Ushio-Fukai, 2011). The decrease in $\mathrm{H}_{2} \mathrm{O}_{2}$ concentrations caused by the activity of other enzymes (e.g., CAT and APX) may have provided an environment where there was no stimulus for SOD synthesis. Some studies have already shown that Se negatively impacts SOD activity in plants (Hartikainen et al., 2000; Xue and Hartikainen, 2000; Cheng et al., 2016; Reis et al., 2018).

Due to the very high doses of Se used in the present experiment, Se was observed to play a physiological role as a pro-oxidative agent, increasing the concentrations of $\mathrm{H}_{2} \mathrm{O}_{2}$, which may stimulate SOD activity in the 800 and $1200 \mathrm{~g} \mathrm{ha}^{-1}$ treatments. The same is true for APX, an enzyme that uses ascorbate as an electron donor to reduce $\mathrm{H}_{2} \mathrm{O}_{2}$ to $\mathrm{H}_{2} \mathrm{O}$ (Caverzan et al., 2012) and showed higher activity in plants exposed to high Se concentrations (Fig. 2c).

SOD, CAT, APX, and GR present peaks of activity at different Se concentrations, indicating that the element might be stimulating or suppressing different enzymes depending on its concentrations. According to Stewart et al. (1999), Se can catalyze the oxidation of thiol groups, promoting the release of superoxide $\left(\mathrm{O}_{2}{ }^{-}\right)$, which may be one of the reasons the plants present stress symptoms.
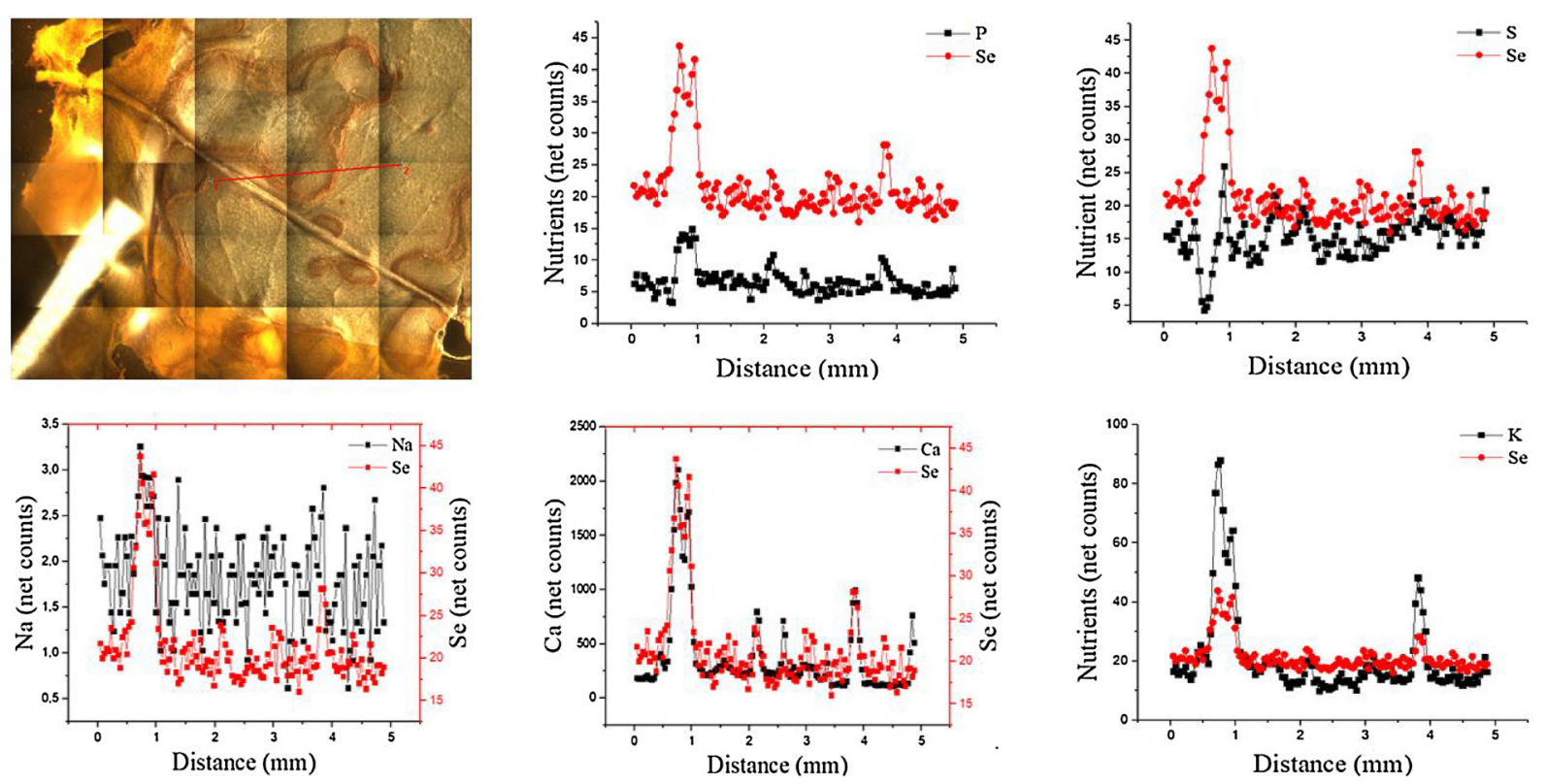

Fig. 9. Distribution of elements in leaves of cowpea plants sprayed with Se at $1600 \mathrm{~g} \mathrm{ha}^{-1}$ Se observed using $\mu$-XRF. 


\subsection{Photoassimilates and photosynthetic pigments}

Increases in sucrose and total sugar concentration up to the 400 and $800 \mathrm{~g} \mathrm{ha}^{-1}$ treatments may be due to the activity of carbohydrate metabolism enzymes. Malik et al. (2011) observed that mung bean (Phaseolus aureus Roxb.) exposed to Se showed increased activity of amylases and invertases. Additionally, the stress generated by Se may itself have induced an increase in the accumulation of sugars in the leaf tissue.

Evidence that soluble sugars can be reduced has also been found. Ribeiro et al. (2016) observed lower starch degradation at nightfall in Arabidopsis thaliana under increased Se conditions, as well as a reduction in the concentration of saccharides and hexoses in the same period.

Among the observed variables, photosynthetic pigments were most sensitive to high doses of Se. A reduction in the leaf concentration of chlorophylls and carotenoids with the increased Se concentration has already been described for maize (Jiang et al., 2017).

\subsection{Yield components and nutritional analysis}

The increased yield observed in the plants with the application of $50 \mathrm{~g} \mathrm{ha}^{-1}$ Se (Fig. 4b), as well as the increase in foliar sucrose concentration (Fig. 3), may be linked to the effect of Se in the mitigation of oxidative stress (Fig. 1). At $50 \mathrm{~g} \mathrm{ha}^{-1}$, visual effects of Se toxicity were not observed (Figs. 6 and 7).

The effect of Se on crop productivity is still controversial, but the beneficial effect of this element has previously been observed on the yield components of cowpea (Manaf, 2016) and other crops, such as mungbean (Kaur and Nayyar, 2015) and wheat (Yao et al., 2013), which agrees with the findings of the present study.

The leaf concentration of Se (Fig. 4a) in plants that received the highest concentration treatments reached values close to $100 \mathrm{mg} \mathrm{kg}^{-1}$, which is considered the upper limit tolerated by non-Se-accumulator plants (White, 2016). Regarding concentration of Se in seeds, an intake of up to $0.1 \mathrm{mg}$ of Se per day is recommended for adults (Monsen, 2000), which is equivalent to a daily intake of more than $50 \mathrm{~g}$ of cowpea from the $50 \mathrm{~g} \mathrm{ha}^{-1}$ treatment in our study (Fig. 4b).

Absorption of selenite through the roots is partially mediated by phosphate transporters (Li et al., 2008). However, under the conditions in the present study, Se was supplied in foliar applications, so the absorption of the selenite can occur passively (Gupta and Gupta, 2017), which explains the direct relation between the applied concentrations and the observed Se concentration. Selenite is rapidly converted to organoselenium compounds, such as selenocysteine (SeCys) and selenomethionine (SeMet) (White, 2016). The ease of assimilation of high amounts of selenite into sulfuric amino acids may have compromised the foliar concentration of $\mathrm{S}$ as observed in some treatments. The interaction between trace elements (such as Se) and micronutrients and other trace elements is a complex process, and sometimes, these elements may naturally present synergistic and antagonistic relations at the same time (Kabata-Pendias and Pendias, 2011).

\subsection{Ultrastructure and $\mu$-XRF nutrient distribution analysis}

Selenium treatments showed direct effects on the diameter of the phloem (Fig. 5a), compared to the xylem (Fig. 5b), likely due to the application method (foliar), which favors the dispersion of the element through the phloem.

Visual observation of the effects of leaf tissue damage was possible (Figs. 6 and 7). No effect on the adaxial and abaxial epidermis thickness was observed (Fig. 5c, d); however, a decrease in the palisade parenchyma thickness was observed. This indicates that the solutes were translocated through the first layer of the cells so that the toxic effect manifested in the palisade cells. Se can compromise the plant as a prooxidant (Hartikainen et al., 2000) or by inducing malformation of selenoproteins due to excess SeCys and SeMet compared to the sulfur forms of these amino acids (Gupta and Gupta, 2017).

The incidence of toxicity was observed mainly near the trichomes (Fig. 7). Although the action of trichomes on water absorption is commonly associated with epiphytes, the effect of these structures on absorption has even been observed in forest trees (Eller et al., 2016) and Caatinga trees (Pina et al., 2017). No reports exist in the literature about the accumulation of Se in plant trichomes. However, trichomes might be regions of accumulation of Se and $\mathrm{Na}$ in foliar tissue, as already demonstrated for the accumulation of $\mathrm{Mn}$ in the trichomes in sunflower leaves (Blamey et al., 2015).

To our knowledge, no study characterizing necrotic lesions caused by toxicity of sodium selenite has been previously published. Therefore, this is the first study to characterize the toxicity of sodium selenite to plants. The distributions of the elements in the parts of the plant tissue, as shown by X-ray spectrometry (Fig. 8), are indicated by the highest K$\alpha$ readings of $\mathrm{Se}, \mathrm{S}, \mathrm{Ca}, \mathrm{K}, \mathrm{Co}, \mathrm{Cu}$, and $\mathrm{Mn}$ near the conductive vessels. This is probably due to the time of sampling ( $48 \mathrm{~h}$ after application). Symptoms of toxicity were observed $48 \mathrm{~h}$ after the foliar application of sodium selenite. Therefore, the higher readings of these nutrients in the conductive vessels was likely due to insufficient time for the migration of the elements to other parts of the leaf tissue. In addition, damage to trichomes, cells, and stomata, as observed in Fig. 7, may have contributed to compromising the natural pattern of the elements in the plant tissue.

In addition to the conductive vessels, high $\mathrm{K}-\alpha$ counts of Se and other micronutrients mentioned above were observed in the necrotic brown region on the leaf (Fig. 9a). The antagonistic relation between Se and $\mathrm{S}$ is apparent in Fig. 9c. The similarity between the deposition of Se and Ca suggests that $\mathrm{Ca}$ has an important role in the attempt to relieve stress in the damaged area. The accumulation of $\mathrm{Ca}$ in damaged areas has already been observed in toxicity experiments with other elements, such as Mn (Blamey et al., 2015; Santos et al., 2017). Calcium accumulation may be a response to prevent cell degradation due to the role of the element in inhibiting enzyme activity during pectin polygalacturonase degradation (Hawkesford et al., 2012). However, the study in question does not directly show this relation with $\mathrm{Ca}$, so future research should be developed to better investigate the role of $\mathrm{Ca}$ in $\mathrm{Se}$ toxicity in plants.

\section{Conclusions}

The application of Se at concentrations higher than $50 \mathrm{~g} \mathrm{ha}^{-1}$ induces a reduction in phloem diameter and palisade parenchyma thickness. Toxicity symptoms are characterized by brown necrotic lesions next to the trichomes. The decrease in lipid peroxidation and in $\mathrm{H}_{2} \mathrm{O}_{2}$ concentration observed in selenium treatments with concentrations under $1200 \mathrm{~g} \mathrm{ha}^{-1}$ is a response of the plant to stress.

The highest concentrations of $\mathrm{Se}, \mathrm{K}, \mathrm{Ca}, \mathrm{Cu}$, and $\mathrm{Mn}$ are found in conductive vessels, whereas $\mathrm{Na}$ is more homogeneously distributed in the plant tissue.

Further studies on the effects of Se on agronomic and structural characteristics of cowpea should be conducted to better understand the effects of Se on this plant.

\section{Conflict of interest}

The authors have no conflicts of interest to declare.

\section{Acknowledgments}

We acknowledge Dr. Luciano Alves dos Anjos for the availability of the stereomicroscope, and Dr. Marco Eustáquio de Sá and Dr. Liliane Santos de Camargos for their valuable intellectual input to the study. We thank Lolita Wilson and Dr. Scott Young for the nutrient plant tissue analysis. Support for this research was provided by the FAPESP (São Paulo Research Foundation - Process number: 2015/19121-8 and 
2016/19773-8)

\section{Appendix A. Supplementary data}

Supplementary data associated with this article can be found, in the online version, at https://doi.org/10.1016/j.envexpbot.2018.03.020.

\section{References}

Alexieva, V., Sergiev, I., Mapelli, S., Karanov, E., 2001. The effect of drought and ultraviolet radiation on growth and stress markers in pea and wheat. Plant Cell Environ. 24, 1337-1344.

Azevedo, R.A., Alas, R.M., Smith, R.J., Lea, P.J., 1998. Response of antioxidant enzymes to transfer from elevated carbon dioxide to air and ozone fumigation, in the leaves and roots of wild-type and a catalase-deficient mutant of barley. Physiol. Plant. 104, 280-292.

Bieleski, R.L., Turner, N.A., 1966. Separation and estimation of amino acids in crude plant extracts by thin-layer electrophoresis and chromatography. Anal. Biochem. 17, 278-293.

Blamey, P., Hernandez-Soriano, M., Cheng, M., Tang, C., Paterson, D., Lombi, E., Kopittke, P.M., 2015. Synchrotron-based techniques shed light on mechanisms of plant sensitivity and tolerance to high manganese in the root environment. Plant Physiol. 169, 2006-2020.

Bradford, M., 1976. A rapid and sensitive method for the quantitation of microgram quantities of protein utilizing the principle of protein-dye binding. Anal. Biochem. 72, 248-259.

Broadley, M.R., White, P.J., Bryson, R.J., Meacham, M.C., Bowen, H.C., Johnson, S.E., Hawkesford, M.J., McGrath, S.P., Zhao, F.J., Breward, N., Harriman, M., Tucker, M., 2006. Biofortification of U.K. food crops with selenium (Se). Proc. Nutr. Soc. 65 , 169-181.

Broadley, M.R., Alcock, J., Alford, J., Cartwright, P., Fairweather-Tait, S.J., Foot, I., Hart, D.J., Hurst, R., Knott, P., McGrath, S.P., Meacham, M.C., Norman, K., Mowat, H., Scott, P., Stroud, J.L., Tovey, M., Tucker, M., White, P.J., Young, S.D., Zhao, F.J., 2010. Selenium biofortification of high-yielding winter wheat (Triticum aestivum L.) by liquid or granular Se fertilisation. Plant Soil 332, 5-18.

Caverzan, A., Passaia, G., Rosa, S.B., Ribeiro, C.W., Lazzarotto, F., Margis-Pinheiro, M., 2012. Plant responses to stresses: role of ascorbate peroxidase in the antioxidant protection. Genet. Mol. Biol. 35, 1011-1019.

Cheng, B., Lian, H.-F., Liu, Y.-Y., Yu, X.-H., Sun, Y.-L., Sun, X.-D., Liu, S.Q., 2016. Effects of selenium and sulfur on antioxidants and physiological parameters of garlic plants during senescence. J. Integr. Agric. 15, 566-572.

Chilimba, A.D.C., Young, S.D., Black, C.R., Meacham, M.C., Lammel, J., Broadley, M.R., 2012. Agronomic biofortification of maize with selenium (Se) in Malawi. Field Crops Res. 125, 118-128.

Combs, G.F., 2001. Selenium in global food systems. Br. J. Nutr. 85, 517-547.

Demattê, J., 1980. Levantamento Detalhado dos Solos do Campus Experimental de Ilha Solteira. Escola Superior de Agricultura Luiz de Queiroz, Piracicaba.

Dubois, M., Gilles, K.A., Hamilton, J.K., Rebers, P.A., Smith, F., 1956. Colorimetric method for determination of sugars and related substances. Anal. Chem. 28, 350-356.

EMBRAPA (Empresa Brasileira de Pesquisa Agropecuária), 2013. Sistema Brasileiro de Classificação de Solos. Embrapa Solos, Rio-de-Janeiro.

Ehlers, J.D., Hall, A.E., 1997. Cowpea (Vigna unguiculata L. Walp.). Field Crops Res. 53, 187-204.

Eller, C.B., Lima, A.L., Oliveira, R.S., 2016. Cloud forest trees with higher foliar water uptake capacity and anisohydric behavior are more vulnerable to drought and climate change. New Phytol. 211, 489-501.

Fairweather-Tait, S.J., Bao, Y., Broadley, M.R., Collings, R., Ford, D., Hesketh, J.E., Hurst, R., 2011. Selenium in human health and disease. Antioxid. Redox Signaling 14, 1337-1383.

Fatalieva, S.M., 1987. Ultrastructure of mesophyll cells grown on different levels of selenium of two pea genotypes. In: Gabelman, W.H., Loughman, B.C. (Eds.), Genetic Aspects of Plant Mineral Nutrition. Developments in Plant and Soil Sciences. Springer, Dordrecht, pp. 471-476.

Fukai, T., Ushio-Fukai, M., 2011. Superoxide dismutases: role in redox signaling, vascular function, and diseases. Antioxid. Redox Signaling 15, 1583-1606.

Giannopolitis, C.N., Ries, S.K., 1977. Superoxide dismutases: I. Occurrence in higher plants. Plant Physiol. 59, 309-314.

Gomes-Junior, R.A., Moldes, C.A., Delite, F.S., Pompeu, G.B., Gratão, P.L., Mazzafera, P., et al., 2006. Antioxidant metabolism of coffee cell suspension cultures in response to cadmium. Chemosphere 65, 1330-1337.

Gomes-Junior, R.A., Gratão, P.L., Gaziola, S.A., Mazzafera, P., Lea, P.J., Azevedo, R.A., 2007. Selenium-induced oxidative stress in coffee cell suspension cultures. Funct. Plant Biol. 34, 449-456.

Gupta, M., Gupta, S., 2017. An overview of selenium uptake, metabolism, and toxicity in plants. Front. Plant Sci. 7, 2074.

Hall, A.E., 2012. Phenotyping cowpeas for adaptation to drought. Front. Physiol. 3, 155. Hartikainen, H., Xue, T., Piironen, V., 2000. Selenium as an anti-oxidant and pro-oxidant in ryegrass. Plant and Soil 225, 193-200.

Hawkesford, M., Horst, W., Kichey, T., Lambers, H., Schjoerring, J., Møller, I.S., White, P., 2012. Functions of macronutrients. In: Marschner, P. (Ed.), Marschner's Mineral Nutrition of Higher Plants. Academic Press, San Diego, pp. 135-189.

Heath, R.L., Packer, L., 1968. Photoperoxidation in isolated chloroplast. I. Kinetics and stoiichiometry of fatty acid peroxidation. Arch. Biochem. Biophys. 125, 2141-2145.

Igamberdiev, A.U., Lea, P.J., 2002. The role of peroxisomes in the integration of metabolism and evolutionary diversity of photosynthetic organisms. Phytochemistry 60, 651-674.

Jiang, C., Zu, C., Lu, D., Zheng, Q., Shen, J., Wang, H., Li, D., 2017. Effect of exogenous selenium supply on photosynthesis, $\mathrm{Na}+$ accumulation and antioxidative capacity of maize (Zea mays L.) under salinity stress. Sci. Rep. 7, 42039.

Joy, E.J.M., Broadley, M.R., Young, S.D., Black, C.R., Chilimba, A.D.C., Ander, E.L., Watts, M.J., 2015. Soil type influences crop mineral composition in Malawi. Sci. Total Environ. 505, 587-595.

Kabata-Pendias, A., Pendias, H., 2011. Trace Elements in Soils and Plants. CRC Press, Boca Raton.

Kaur, S., Nayyar, H., 2015. Selenium fertilization to salt-stressed mungbean (Vigna radiata L. Wilczek) plants reduces sodium uptake, improves reproductive function, pod set and seed yield. Sci. Hortic. 197, 304-317.

Lavres Junior, J., Reis, A.R., Rossi, M.L., Cabral, C.P., Nogueira, N.D.L., Malavolta, E., 2010. Changes in the ultrastructure of soybean cultivars in response to manganese supply in solution culture. Scientia Agricola 67, 287-294.

Li, H.-F., Mcgrath, S.P., Zhao, F.-J., 2008. Selenium uptake, translocation and speciation in wheat supplied with selenate or selenite. New Phytol. 178, 92-102.

Lichtenthaler, H.K., 1987. Chlorophylls and carotenoids: pigments of photosynthetic biomembranes. Methods Enzymol. 148, 350-382.

Luo, Z.B., He, J., Polle, A., Rennenberg, H., 2016. Heavy metal accumulation and signal transduction in herbaceous and woody plants: paving the way for enhancing phytoremediation efficiency. Biotechnol. Adv. 34, 1131-1148.

Malik, J.A., Kumar, S., Thakur, P., Sharma, S., Kaur, N., Kaur, R., et al., 2011. Promotion of growth in mungbean (Phaseolus aureus roxb.) by selenium is associated with stimulation of carbohydrate metabolism. Biol. Trace Elem. Res. 143, 530-539.

Manaf, H.H., 2016. Beneficial effects of exogenous selenium, glycine betaine and seaweed extract on salt stressed cowpea plant. Ann. Agric. Sci. 61, 41-48.

Manzeke, M.G., Mtambanengwe, F., Nezomba, H., Watts, M.J., Broadley, M.R., Mapfumo, P., 2017. Zinc fertilization increases productivity and grain nutritional quality of cowpea (Vigna unguiculata [L.] Walp.) under integrated soil fertility management. Field Crops Res. 213, 231-244.

Moldes, C.A., Medici, L.O., Abrahão, O.S., Tsai, S.M., Azevedo, R.A., 2008. Biochemical responses of glyphosate resistant and susceptible soybean plants exposed to glyphosate. Acta Physiologiae Plantarum 30, 469-479.

Molnárová, M., Fargašová, A., 2009. Se(IV) phytotoxicity for monocotyledonae cereals (Hordeum vulgare L., Triticum aestivum L.) and dicotyledonae crops (Sinapis alba L., Brassica napus L.). J. Hazard. Mater. 172, 854-861.

Monsen, E.R., 2000. Dietary reference intakes for the antioxidant nutrients: vitamin C, vitamin E, selenium, and carotenoids. J. Am. Diet. Assoc. 100, 637-640.

Mostofa, M.G., Hossain, M.A., Siddiqui, M.N., Fujita, M., Tran, L.S.P., 2017. Phenotypical: physiological and biochemical analyses provide insight into selenium-induced phytotoxicity in rice plants. Chemosphere 178, 212-223.

Noctor, G., Mhamdi, A., Chaouch, S., Han, Y.I., Neukermans, J., Marquez-Garcia, B., Foyer, C.H., 2012. Glutathione in plants: an integrated overview. Plant Cell Environ. 35, 454-484.

Phillips, R.D., Mcwatters, K.H., Chinnan, M.S., Hung, Y.-C., Beuchat, L.R., Sefa-Dedeh, S., Saalia, F.K., 2003. Utilization of cowpeas for human food. Field Crops Res. 82, 193-213.

Pilon-Smits, E.A.H., Quinn, C.F., Tapken, W., Malagoli, M., Schiavon, M., 2009. Physiological functions of beneficial elements. Curr. Opin. Plant Biol. 12, 267-274.

Pina, A.L.C.B., Zandavalli, R.B., Oliveira, R.S., Martins, F.R., Soares, A.A., 2017. Dew absorption by the leaf trichomes of Combretum leprosum in the Brazilian semiarid region. Funct. Plant Biol. 43, 851-861.

Raij, B.V., De Andrade, J.C., Cantarella, H., Quaggio, J.A., 1997. Análise Química Para Avaliação da Fertilidade de Solos Tropicais. Instituto Agronômico de Campinas, Campinas.

Reis, A.R.D., El-Ramady, H., Santos, E.F., Gratão, P.L., Schomburg, L., 2017a. Overview of selenium deficiency and toxicity worldwide: affected areas, selenium-related health issues, and case studies. In: Pilon-Smits, E.A.H., Winkel, L.H.E., Lin, Z.-Q. (Eds.), Selenium in Plants: Molecular, Physiological, Ecological and Evolutionary Aspects. Springer International Publishing, Cham, pp. 209-230.

Reis, A.R., Barcelos, J.P.Q., Osório, C.R.W.S., Santos, E.F., Lisboa, L.A.M., Santini, J.M.K., Santos, M.J.D., Furlani Junior, E., Campos, M., Figueiredo, P.A.M., Lavres, J., Gratão, P.L., 2017b. A glimpse into the physiological: biochemical and nutritional status of soybean plants under Ni-stress conditions. Environ. Exp. Bot. 144, 78-87.

Reis, H.P.G., Barcelos, J.P.Q., Furlani Junior, E., Santos, E.F., Silva, V.M., Moraes, M.F., Putti, F.F., Reis, A.R., 2018. Agronomic biofortification of upland rice with selenium and nitrogen and its relation to grain quality. J. Cereal Sci. 79, 508-515.

Ribeiro, D.M., Silva Júnior, D.D., Cardoso, F.B., Martins, A.O., Silva, W.A., Nascimento, V.L., Araújo, W.L., 2016. Growth inhibition by selenium is associated with changes in primary metabolism and nutrient levels in Arabidopsis thaliana. Plant Cell Environ. 39, 2235-2246.

Ros, G.H., Van Rotterdam, A.M.D., Bussink, D.W., Bindraban, P.S., 2016. Selenium fertilization strategies for bio-fortification of food: an agro-ecosystem approach. Plant Soil 404, 99-112.

Santos, E.F., Kondo Santini, J.M., Paixão, A.P., Júnior, E.F., Lavres, J., Campos, M., Reis, A.R.D., 2017. Physiological highlights of manganese toxicity symptoms in soybean plants: Mn toxicity responses. Plant Physiol. Biochem. 113, 6-19.

Schiavon, M., Pilon-Smits, E.A.H., 2017. The fascinating facets of plant selenium accumulation - biochemistry, physiology, evolution and ecology. New Phytol. 213, 1582-1596.

Shi, G.W., Li, H., Liu, T.X., Polle, A., Peng, C.H., Luo, Z.B., 2016. Exogenous abscisic acid alleviates zinc uptake and accumulation in Populus $\times$ canescens exposed to excess 
zinc. Plant Cell Environ. 38, 207-223.

Slusarczyk, J., Wierzbicka, M., Suchocki, P., Kuraś, M., 2015. Ultrastructural changes in onion (Allium cepa L.) root tip meristem cells treated with Selol and sodium selenate (IV). Caryologia: Int. J. Cytol. Cytosyst. Cytogenet. 68, 306-316.

Stewart, M.S., Spallholz, J.E., Neldner, K.H., Pence, B.C., 1999. Selenium compounds have disparate abilities to impose oxidative stress and induce apoptosis. Free Radic. Biol. Med. 26, 42-48.

Thomas, C.L., Alcock, T.D., Graham, N.S., Hayden, R., Matterson, S., Wilson, L., Young, S.D., Dupuy, L.X., White, P.J., Hammond, J.P., Danku, J.M.C., Salt, D.E., Sweeney, A., Bancroft, I., Broadley, M.R., 2016. Root morphology and seed and leaf ionomic traits in a Brassica napus L. diversity panel show wide phenotypic variation and are characteristic of crop habit. BMC Plant Biol. 16, 214.

Van Handel, E., 1968. Direct microdetermination of sucrose. Anal. Biochem. 22, 280-283.

White, P.J., Broadley, M.R., 2009. Biofortification of crops with seven mineral elements often lacking in human diets - iron, zinc, copper, calcium, magnesium, selenium and iodine. New Phytol. 182, 49-84.

White, P.J., Bowen, H.C., Parmaguru, P., Fritz, M., Spracklen, W.P., Spiby, R.E., Meacham, M.C., Mead, A., Harriman, M., Trueman, L.J., Smith, B.M., Thomas, B. Broadley, M.R., 2004. Interactions between selenium and sulphur nutrition in Arabidopsis thaliana. J. Exp. Bot. 55, 1927-1937.

White, P.J., 2016. Selenium accumulation by plants. Ann. Bot. 117, 217-235.

Wrzaczek, M., Brosché, M., Kangasjärvi, J., 2013. ROS signaling loops-production perception, regulation. Curr. Opin. Plant Biol. 16, 575-582.

Xue, T., Hartikainen, H., 2000. Association of antioxidative enzymes with the synergistic effect of selenium and UV irradiation in enhancing plant growth. Agric. Food Sci Finland 9, 177-186.

Yao, X., Jianzhou, C., Xueli, H., Binbin, L., Jingmin, L., Zhaowei, Y., 2013. Effects of selenium on agronomical characters of winter wheat exposed to enhanced ultravioletB. Ecotoxicol. Environ. Saf. 92, 320-326. 